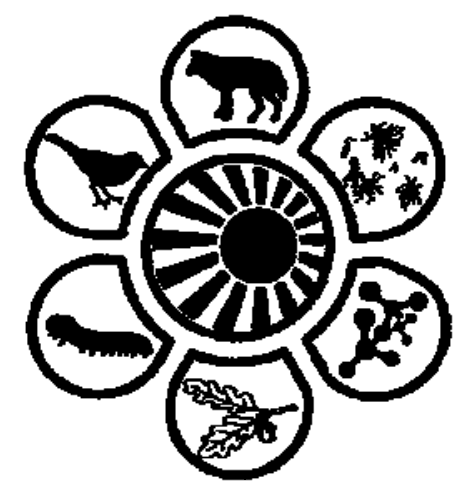

Вісник Дніпропетровського університету. Біологія, екологія.

Vìsnik Dnìpropetrovs'kogo unìversitetu. Seriâ Bìologiâ, ekologiâ

Visnyk of Dnipropetrovsk University. Biology, ecology.

Vìsn. Dnìpropetr. Unìv. Ser. Bìol. Ekol. 2014. 22(1), 33-37.

doi:10.15421/011404

ISSN 2310-0842 print

ISSN 2312-301X online

www.ecology.dp.ua

\title{
УДК 581.5(477.87):631.842
}

\section{Аліментарні тригери гормонзалежних форм раку молочної залози}

\author{
Т.Ю. Лихолат ${ }^{1}$, О.А. Лихолат ${ }^{2}$, В.С. Недзвецький ${ }^{1}$, В.В. Лактіонов ${ }^{3}$ \\ ${ }^{1}$ Дніпропетровський начіональний університет імені Олеся Гончара, Дніпропетровськ, Украӥна \\ ${ }^{2}$ Академія митної служби України, Дніпропетровськ, Україна \\ ${ }^{3}$ Комунальний заклад «Центральна міська лікарня», Новомосковськ, Украӥна
}

Досліджено процеси перекисного окиснення ліпідів і стан системи антиокисного захисту в організмі щурів різного віку, що піддавалися впливу екзоестрогенів. Установлено різний ступінь інтенсифікації пероксидації залежно від віку та дослідного органа: максимальне перевищення контрольних показників відмічене у сироватці крові, що свідчить про вплив синтетичних естрогенів на всі основні системи організму. У самиць у препубертатному періоді у печінці реакція прооксидантної системи та напруження в системі антиоксидантного захисту перевищували силу відповіді в органі статевозрілих тварин. Відмічено органну дискретність змін активності ензимів антиоксидантного захисту, яка залежить від віку тварин. Ураховуючи залучення системи глутатіону до дезактивації естрогенів шляхом їх кон'югації в реакціях, що каталізуються глутатіонтрансферазою, зниження активності ензиму може викликати накопичення високоактивних проміжних метаболітів із наступним пошкодженням внутрішньоклітинних структур. Ці феномени надалі можуть стати тригером зниження потенціалу компенсаторних механізмів, що разом із генотоксичною дією екзоестрогенів $\epsilon$ важливою патогенетичною ланкою в канцерогенезі: ініціюють розвиток проліферативних процесів та виникнення в майбутньому ракових станів i, зокрема, гормонзалежних пухлин молочної залози.

Ключові слова: екзоестрогени; перекисне окиснення ліпідів; система антиоксидантного захисту

\section{Alimentary triggers of hormone dependent breast cancers}

\author{
T.Y. Lykholat ${ }^{1}$, O.A. Lykholat ${ }^{2}$, V.S. Nedzvetsky ${ }^{1}$, V.V. Laktionov ${ }^{3}$ \\ ${ }^{l}$ Oles Honchar Dnipropetrovsk National University, Dnipropetrovsk, Ukraine \\ ${ }^{2}$ Academy of Customs Service of Ukraine, Dnipropetrovsk, Ukraine \\ ${ }^{3}$ Central Hospital Munisipal Enterprise, Novomoskovsk, Ukraine
}

Breast cancer (BC) consistently holds the leading positions in the structure of morbidity and mortality of the female population. Food containing veterinary hormones is extremely dangerous to human health: estrogens are female sex hormones. Excessive level of estrogen in the body gives rise to diseases of varying severity: in women (especially of older age) it may cause breast cancer. The paper investigates the processes of lipid peroxidation and the status of antioxidant protection system in rats of different ages exposed to exogenous estrogens. The purpose of the work is to study lipid peroxidation and antioxidative protection status in rats of different ages exposed to exogenous estrogens for determining the trigger mechanisms for tumor development. Experiments were conducted on female Wistar rats exposed to exogenous estrogen for 45 days. At the beginning of the experiment, age of experimental animals was 3 months in pubertal period and 6 months as mature ones. The control groups consisted of intact animals of appropriate age. To simulate the influence of exogenous estrogen, rats' food was treated with the Sinestron drug at the rate of $2 \mathrm{mg}$ per $\mathrm{kg}$. The research materials were serum and liver of rats. Objects of the research

Дніпропетровський наиіональний університет імені Олеся Гончара, пр. Гагаріна, 72, Дніпропетровськ, 49010, Украӥна. Oles Honchar Dnipropetrovsk National University, Gagarin Ave., 72, Dnipropetrovsk, 49010, Ukraine.

Tel.: +38-050-229-19-61. E-mail: lykholat2010@ukr.net

Академія митної служби України, вул. Дзержинського, 2/4, Дніпропетровськ, 49000, Україна. Academy of Custom Service of Ukraine, Dzerzhinsky st., 2/4, Dnipropetrovsk, 49000, Ukraine.

Tel.: +38-066-038-68-92. E-mail: lykholat2010@ukr.net

Комунальний заклад «Центральна міська лікарня», вул. Сучкова, 40, Новомосковськ, 51200, Украйна. Central Hospital Munisipal Enterprise, Suchkov st., 40, Novomoskovsk, 51200, Ukraine.

Tel.: +38-095-276-09-62.E-mail:197306@mail.ruukr.net 
were indicators of lipid peroxidation activity (content of TBA-active products) and antioxidant protection system (reduced glutathione (RG) level), glutathione transferase (GT), glutathione reductase (GR), glutathione peroxidase (GP), superoxide dismutase (SOD) activity, and total antioxidative activity (AOA). Data obtained was treated with standard methods of estimation of variation series. Various degrees of peroxidation intensification depending on the age and organs were determined. Maximum excess of control indexes in the serum was observed and it indicated synthetic estrogen effect of on all major body systems. In prepubertal period females' liver the reaction of prooxidant system and tension in the antioxidant protection system exceeded the strength of response in the body of mature animals. The organ discreteness of changes in the activity of antioxidant protection enzymes depending on the age of the animals was recorded. Given the involvement of glutathione system in the deactivation of estrogens through their conjugation in reactions catalyzed by glutathione transferase, decreased enzyme activity may lead to accumulation of highly active intermediate metabolites with subsequent damage to intracellular structures. Later on, these phenomena may become a trigger of reduction of the compensatory mechanisms' potential, which together with the genotoxic effect of exogenous estrogens is an important pathogenetic element in carcinogenesis: they initiate the development of proliferative processes and occurrence of cancer conditions, in particular, hormone dependent breast tumors, in future.

Keywords: exogenous estrogens; lipid peroxidation; antioxidant protection system

\section{Вступ}

Рак молочної залози (РМЗ) у структурі захворюваності та смертності жіночого населення стійко займає лідируючі позиції. У світі щорічно реєструється понад 1 млн випадків даного захворювання, гинуть від нього близько 250 тис. жінок. Якщо загальна захворюваність злоякісними пухлинами з віком збільшується, досягаючи максимуму до $70-80$ років, то при раку молочної залози пік захворюваності припадає на 4559 років. У структурі онкологічної захворюваності жінок в Україні РМЗ посідає перше місце. Рівень захворюваності на РМЗ в Україні за останні 45 років (19652010) зріс із 17,6 до 69,7 на 100 тис. жіночого населення, за останні 20 років - у 2,5 раза, щорічний приріст цієї онкопатології становить понад 2\%. За даними Національного канцер-реєстру, щорічно в Україні реєструють понад 16,5 тис. нових випадків РМЗ, серед яких 25\% - жінки репродуктивного віку (Lykholat, 2012; Fedorenko et al., 2013; Smolanka et al., 2013).

Рак молочної залози є патологією з дуже широкою варіацією частоти між різними географічними районами та групами населення: відмінності між регіонами з високим ризиком (Свропа, Північна Америка, Австралія) та низьким (Латинська Америка, Азія, включаючи Японію, Африка) - більше ніж 8-кратні. Майже повселюдно констатується вища захворюваність жінок, що проживають у великих містах, ніж мешканок маленьких містечок i сільських місцевостей. Крім того, в індустріально розвинених районах жінки хворіють частіше. Подібні явища, вірогідно, пов'язані з впливом екзогенних чинників, що здатні ініціювати процеси канцерогенезу в організмі.

Харчування становить 30-35\% факторів ризику, які сприяють виникненню пухлин. Деякі харчові продукти та раціон пов'язані з виникненням різних видів раку. У сучасному промисловому тваринництві, птахівництві та рибництві за інтенсивних технологій вирощування тварин, у порушення технологічних регламентів часто незаконно застосовують шкідливі для здоров'я людини гормональні стимулятори росту, тому що вони дозволяють домогтися значного підвищення продуктивності тваринництва (Stephany, 2001, 2010; Brynes, 2005). Продукція, що вміщує ветеринарні препарати, вкрай небезпечна для здоров'я людини: гормональні стимулятори росту - стильбени, стероїдні гормони мають канцерогенну активність, викликають порушення статевого дозрівання та репродуктивної здатності (Larrea and
Chirinos, 2007; Wang and Wang, 2007). Гормони не повністю руйнуються за теплової обробки продуктів. Тому всі гормони, спочатку присутні в м'ясі, молоці, яйцях, овочах і фруктах, там і залишаються, хоча іноді й у менших дозах. Стероїдні гормони руйнуються під час теплової обробки найменше (Chun, 2012). Чоловічі та жіночі гормони містяться в м'ясі (яловичині, свинині, курятині), жіночі - у молоці та яйцях, фітогормони - в овочах i фруктах. Найбільшу популярність здобув фітоестроген, що міститься у сої. Статеві гормони тварин ідентичні гормонам людини. Таким чином, усі гормони, які застосовуються у тваринництві, здатні впливати на людський організм. Потрапляючи до організму людини з їжею, ці гормони сприймаються ним як власні (Brinkman, 2010; Boucher, 2012).

Естрогени - група жіночих статевих гормонів, що синтезуються в організмі яєчниками та регулюють специфічні статеві функції. Надмірний рівень естрогену в організмі буває причиною захворювань різного ступеня тяжкості: у жінок (особливо літнього віку) він здатний викликати рак грудей (Fung et al., 2006; Lykholat et al., 2013). Однак результати досліджень не дозволяють отримати однозначні та послідовні докази про асоціацію між дієтою та розвитком канцерогенезу: прямої кореляції між раціоном і захворюванням на рак молочної залози не виявлено, але є вагомі підстави вважати, що споживання великої кількості жирів тваринного походження (із м'ясом і молочними продуктами) може сприяти його розвитку, можливо, у результаті підвищення рівнів естрогену, що циркулює в організмі (Baena et al., 2013).

Найбільш відповідальний період постнатального онтогенезу - статеве дозрівання (пубертатний період). У пубертатному періоді виділяють дві фази: ранню (препубертатну) та зрілу (власне пубертатну). Власне пубертатна фаза характеризується найзначнішими зрушеннями морфофункціональних параметрів, тому існує підвищення імовірності відхилень показників здоров'я. Головна подія цього періоду - дозрівання системи взаємодії «гіпоталамус - гіпофіз - гонади». У препубертатному та пубертатному періодах кількість гормонів, що зумовлюють формування жіночого фенотипу та секретуються гіпофізом і яєчниками, поступово збільшується. Статеві гормони разом з іншими факторами, зокрема соматотропним гормоном, викликають великі морфофункціональні зрушення в організмі, здійснюють виражений ефект на біохімічні обмінні процеси, підсилюючи анаболізм, впливають на функцію різних органів і систем організму: при гіпоестрогенії (що 
не відповідає віку) розвиваються остеопороз, гормональна кардіопатія, депресивний стан, сенільні психози; при гіперестрогенії - гіперпластичні процеси та гормонзалежні пухлини (Bouwens et al., 2011).

Мета роботи - оцінити процеси перекисного окиснення ліпідів і стан системи антиокисного захисту в організмі щурів різного віку, що піддавалися впливу екзоестрогенів, для визначення тригерних механізмів розвитку новоутворень.

\section{Матеріал і методи досліджень}

Експерименти проведені на щурах-самках лінії Вістар, яких піддавали впливу екзоестрогену протягом 45 діб. На початок експерименту вік піддослідних тварин складав 3 місяці - у препубертатному періоді (група II, $n=6$ ) та 6 місяців - статевозрілі (група IV, $n=6$ ). Контрольні групи склали інтактні тварини відповідного віку (групи I, $n=$ 6 та III, $n=6$ ).

Для моделювання впливу екзогенного естрогену їжу щурів обробляли препаратом Сінестрон - похідний стильбену, за хімічною будовою відрізняється від стероїдних естрогенних гормонів (жіночих статевих гормонів), але за біологічними та лікувальними властивостями близький до них - у розрахунку 2 мкг/кг маси.

Матеріали дослідження - сироватка крові та печінка щурів. Органи промивали охолодженим фізіологічним розчином i поміщали в охолоджене середовище гомогенізації. Для отримання 10\% гомогенатів тканини подрібнювали на холоду та гомогенізували в гомогенаторі Поттера 3 тефлоновим пестиком у п'ятикратному об'ємі 0,25 М сахарози, виготовленої на 0,001 М розчині ЕДТА.

Оцінювали вміст ТБК-активних продуктів (Gavrilov et al., 1987) та системи антиоксидантного захисту рівень відновленого глутатіону (ВГ) (Owens and Belcher, 1965), активність глутатіонтрансферази (ГТ), глутатіонредуктази (ГР), глутатіонпероксидази (ГП), супероксиддисмутази (СОД) (Pereslegina, 1989), загальної антиокисної активності (Klebanov et al., 1988).

Одержані дані обробляли стандартними методами оцінки варіаційних рядів. Різницю між порівнюваними величинами вважали вірогідною при $P<0,05$. Обчислення виконували за допомогою програмного продукту Statistica 6.0 (StatSoft, США).

\section{Результати та їх обговорення}

За літературними даними, при онкологічних захворюваннях спостерігається порушення окисного гомеостазу у вигляді активації процесів перекисного окиснення ліпідів (ПОЛ) (Boucher et al., 2012). Після проведення досліджень щодо визначення впливу експозиції екзоестрогену на процеси ПОЛ та стан антиоксидантного захисту в органах щурів різного віку були отримані такі результати. У групі щурів у пубертатному періоді рівень ТБК-активних продуктів у печінці перевищував контрольні параметри на 25,6\%, статевозрілих самиць на 18,5\% (табл. 1). У сироватці крові щурів віком 4,5 місяці у препубертатному періоді рівень ТБКАП пе- ревищував контрольні показники на 48,4\%, 7,5 місяців на $51,4 \%$ (табл. 2).

Глутатіон - один із найпотужніших клітинних неензимних антиоксидантів. На синтез цього трипептиду в організмі також впливає вік. Починаючи з 28 років, його виробництво зменшується з кожним роком приблизно на 1\%. Дефіцит глутатіону відмічається при дуже багатьох захворюваннях, зокрема новоутвореннях. Головним органом синтезу відновленого глутатіону у ссавців $\epsilon$ печінка (Akerboom and Sies, 1990). Вміст відновленого глутатіону в печінці щурів групи II перевищував показники відповідної контрольної групи на 39,9\%. У групі IV, яку склали щури старшого віку, підвищення складало $32,4 \%$, що $є$ реактивною відповіддю на пролонгований токсичний вплив. Вживання синтетичних естрогенів спричинює виснаження пулу відновного глутатіону у сироватці: у піддослідних щурів (група II) вміст ВГ був зниженим на $22 \%$ порівняно 3 контролем. У групі IV також зафіксоване падіння рівня відновного глутатіону відносно контрольного показника на 11\%. Зниження рівня глутатіону слугує показником виснаження антиоксидантної системи.

Глутатіонредуктаза (ГР) - значно поширений флавіновий фермент, що підтримує високу внутрішньоклітинну концентрацію відновленої форми глутатіону (GSH). Глутатіонредуктаза має високу специфічність до глутатіону та крім основної, глутатіонвідновної, активності здатна проявляти трансгідрогеназну, електронтрансферазну та діафоразну активності. Глутатіонредуктаза міститься в основному в розчинній частині клітин. Фермент виявлений також у складі хроматину ядер. У піддослідній групі самиць віком 4,5 місяця активність глутатіонредуктази в печінці була на 11,5\% нижчою порівняно 3 контрольною, що є несприятливим чинником виснаження пулу GSH iз часом. У тварин віком 7,5 місяця активність ферменту була вищою на 48,0\%, ніж у інтактних самиць відповідного віку, що, можливо, є проявом адаптивної реакції на токсичну експозицію. За впливу Сінестрону у сироватці крові щурів у препубертатному періоді зафіксовано інгібування ензиму на 17,0\%, статевозрілих - на 8,0\%.

У знешкодженні вторинних продуктів пероксидації та інших окиснених речовин головну роль відіграють глутатіонтрансферази. Вони кон'югують із глутатіоном головні та найтоксичніші продукти перекисного окиснення ліпідів. Відновлення за допомогою глутатіонтрансферази гідропероксидів попереджає прогресування пероксидації та появу іiі вторинних метаболітів. У печінці піддослідних тварин віком 4,5 та 7,5 місяця активність ферменту зростала на 18,3\% і 20,7\%, відповідно. Протилежні зміни активності ензиму детерміновані у сироватці крові щурів обох дослідних груп - зниження на 20,0\% (II група) та 8,0\% (IV група) порівняно $з$ контрольними індексами.

Супероксиддисмутаза здійснює інактивацію радикалів кисню, які виникають у ході біологічних реакцій перенесення електронів або за впливу ксенобіотиків, при різних захворюваннях (Alyaev et al., 2006). Під час визначеня активності СОД у печінці піддослідних груп щурів у препубертатному періоді та у статевозрілих спостерігалась тенденція до зростання на 8,9 i 5,4\%, відповідно. Процеси дисмутації вільних 
радикалів у сироватці крові щурів молодшого віку посилені на 9,0\%, у щурів старшої вікової групи спостерігається тенденція до посилення процесу.

Шляхом відновлення перекисів ліпідів у відповідні спирти та розщеплення пероксиду водню до води глутатіонпероксидаза захищає організм від окиснювального пошкодження (Mariani et al., 2011). Під час визначеня активності ГП, що як донор $H^{+}$використовує відновлений глутатіон, у печінці спостерігалася тенденція до зменшення у дослідній групі II на 4,8\% порівняно 3 контрольними показниками, у статевозрілих тварин навпаки, у дослідній групі знайдене незначне (на 1,7\%) перевищення контролю. У сироватці спостерігалась тенденція до збільшення активності ГП у дослідних групах II та IV на 12 і 5\%, відповідно.

Детермінація інтегрального показника стану антиоксидантних систем - загальної антиоксидантної активності в органах самиць щурів свідчить про різний потенціал захисних систем залежно від віку. У сироватці крові та печінці відмічене підвищення активності антиокисної системи: у самиць віком 4,5 місяця - на 21,0 і 18,1\%, 7,5 місяця - на 28,9 і 13,6\% порівняно 3 контрольними групами відповідного віку.

Показники печінки щурів, аліментарно експозованих екзогенними гормонами, $M \pm m$

Таблиия 1

\begin{tabular}{|l|c|c|c|c|}
\hline \multicolumn{1}{|c|}{ Показники } & I група, $n=6$ & II група, $n=6$ & III група, $n=6$ & IV група, $n=6$ \\
\hline GSH, ммоль/г тканини & $12,9 \pm 0,6$ & $17,5 \pm 0,8^{*}$ & $10,8 \pm 0,5$ & $14,3 \pm 0,7^{*}$ \\
\hline GR, мкмоль/хв г білка & $214,3 \pm 10,7$ & $189,7 \pm 9,5^{*}$ & $139,8 \pm 7,0$ & $206,9 \pm 10,3^{*}$ \\
\hline GST, мкмоль/хв г білка & $487,7 \pm 24,4$ & $576,9 \pm 28,9^{*}$ & $452,5 \pm 22,6$ & $546,2 \pm 27,3^{*}$ \\
\hline TBКАП, нмоль/г білка & $29,1 \pm 1,5$ & $36,6 \pm 1,8^{*}$ & $23,2 \pm 1,2$ & $27,5 \pm 1,4^{*}$ \\
\hline AOA, ум. од. & $26,5 \pm 1,3$ & $31,3 \pm 1,6^{*}$ & $36,6 \pm 1,8$ & $41,6 \pm 2,1^{*}$ \\
\hline COД, опт. од./хв г білка & $236,5 \pm 11,8$ & $257,6 \pm 12,9$ & $254,4 \pm 12,7$ & $268,1 \pm 13,4$ \\
\hline GP, мкмоль/хв г білка & $53,1 \pm 2,7$ & $50,5 \pm 2,5$ & $51,8 \pm 2,6$ & $52,7 \pm 2,6$ \\
\hline
\end{tabular}

Примітка: * (тут і далі) - вірогідність відмінностей показників дослідних груп від контрольних, $P<0,05$.

Табличя 2

Показники сироватки крові щурів, аліментарно експозованих екзогенними гормонами, $M \pm m$

\begin{tabular}{|l|c|c|c|c|}
\hline \multicolumn{1}{|c|}{ Показники } & I група, $n=6$ & II група, $n=6$ & III група, $n=6$ & IV група, $n=6$ \\
\hline $\mathrm{GSH}$, ммоль/мл & $2,60 \pm 0,13$ & $2,01 \pm 0,10^{*}$ & $2,36 \pm 0,12$ & $2,11 \pm 0,10^{*}$ \\
\hline $\mathrm{GR}$, мкмоль/хв мл & $0,42 \pm 0,02$ & $0,35 \pm 0,02^{*}$ & $0,39 \pm 0,02$ & $0,36 \pm 0,02$ \\
\hline $\mathrm{GST}$, мкмоль/хв мл & $9,12 \pm 0,45$ & $7,30 \pm 0,37^{*}$ & $8,79 \pm 0,96$ & $8,09 \pm 0,40^{*}$ \\
\hline TВКАП, нмоль/г білка & $0,75 \pm 0,04$ & $1,11 \pm 0,06^{*}$ & $0,75 \pm 0,04$ & $1,14 \pm 0,57$ \\
\hline AOА, ум. од. & $39,4 \pm 1,9$ & $47,7 \pm 2,4^{*}$ & $38,0 \pm 2,1$ & $49,0 \pm 2,5^{*}$ \\
\hline COД, опт. од./хв & $53,2 \pm 2,7$ & $70,2 \pm 3,5^{*}$ & $55,6 \pm 2,8$ & $59,4 \pm 2,9$ \\
\hline GP, мкмоль/хв мл & $0,088 \pm 0,004$ & $0,099 \pm 0,005^{*}$ & $0,096 \pm 0,005$ & $0,101 \pm 0,005$ \\
\hline
\end{tabular}

Дослідження ефективності впливу екзоестрогенів на перебіг процесів перекисного окиснення ліпідів і стан системи антиокисного захисту в умовах модельного досліду показало різний ступінь інтенсифікації пероксидації залежно від віку та дослідного органа. За отриманими результатами хронічне вживання стероїдних гормонів з їжею викликало напруження прооксидантноантиоксидантної системи, що є неспецифічною реакцією організму на стресові чинники.

Пролонгований системний дисбаланс може в майбутньому реалізуватися в розвиток дистресу, що $є$ одним $з$ основних механізмів виникнення патологічних явищ, зокрема, новоутворень. Оскільки стресовим чинником виступають стероїдні гормони, ймовірно, подібні феномени будуть мати місце, перш за все, в естрогензалежних органах, зокрема молочній залозі.

\section{Висновки}

Аліментарна експозиція естрогенів спричиняє посилення процесів перекисного окиснення ліпідів в організмі тварин у препубертатному періоді та статевозрілих самиць. Установлено різний ступінь інтенсифікації пероксидації залежно від віку та дослідного органа: максимальне перевищення контрольних показників відмічене у сироватці крові, що свідчить про вплив синтетичних естрогенів на всі основні системи організму. У самиць у пубертатному періоді в печінці реакція прооксидантної системи та напруження системи антиоксидантного захисту перевищувала силу відповіді в органі статевозрілих тварин. Відмічено органну дискретність змін активності ензимів антиоксидантного захисту, яка залежить від віку тварин, свідчить про розбалансування роботи ензимів системи глутатіону. Враховуючи залучення системи глутатіону до дезактивації естрогенів шляхом їх кон'югації в реакціях, що каталізуються глутатіонтрансферазою, зниження активності ензиму може спричинювати накопичення високоактивних проміжних метаболітів із наступним пошкодженням внутрішньоклітинних структур. Імбаланс ланки СОД - ГП проявляється накопиченням перекисів, що $\epsilon$ показником розвитку ендогенної інтоксикації, яка більшою мірою виражається у самиць пубертатного періоду.

Порушення окисного гомеостазу у вигляді активації процесів перекисного окиснення ліпідів зі значним накопиченням у крові та печінці початкових і кінцевих продуктів, напруження ферментативної та неферментативної ланок антиоксидантної системи, зниження загальної антиокисної активності сприяють розвитку афектів у системі детоксикації, метаболічної імунодепресії, що проявляється маніфестацією 
ендогенної інтоксикації. Ці феномени надалі можуть стати тригером зниження потенціалу компенсаторних механізмів, що разом із генотоксичною дією екзоестрогенів $\epsilon$ важливою патогенетичною ланкою канцерогенезу: ініціює розвиток проліферативних процесів та виникнення в майбутньому ракових станів i, зокрема, гормонзалежних пухлин молочної залози.

\section{Бібліографічні посилання}

Alyaev, Y.G., Bezrukov, E.A., Tsestiperov, P.A., 2006. Molekulyarnaya patologia raka pretstatel'noy gelezy: Diagnostitcheskaya i prognostitcheskaya znatchimos't osnovnych markerov [Molecular pathology of gland cancer: Diagnostic and prognostic significance of major markers]. Oncourology 2, 45-50.

Baena Ruiz, R., Salinas Hernández, P., 2013. Diet and cancer: Risk factors and epidemiological evidence. Maturitas 13, 360-365.

Boucher, B.A., Cotterchio, M., Curca, I.A., Kreiger, N., Harris, S.A., Kirsh, V.A., Goodwin, P.J., 2012. Intake of phytoestrogen foods and supplements among women recently diagnosed with breast cancer in Ontario, Canada. Cancer. Prev. Control 4(3), 95-107.

Bouwens, C.S., van Rensburg, S.J., de Kock, L., Apffelstaedt, L.P., Kotze, M.J., 2011. Influence of genetic factors on the development of breast cancer in the older woman. Reprod. Toxicol. 3, 302-311.

Brinkman, M.T., Baglietto, L., Krishnan, K., English, D.R, Severi, G., Morris, H.A., Hopper, J.L, Giles, G.G., 2010 Consumption of animal products, their nutrient components and postmenopausal circulating steroid hormone concentrations. Eur. J. Clin. Nutr. 64, 176-183.

Brynes, S.D., 2005. Demystifying 21 CFR Part 556 tolerances for residues of new animal drugs in food. Regul. Toxicol. Pharmacol. 42(3), 324-327.

Chun, J., Pocock, B., Joseph, K.A., Tamer, E.M., Klein, L., Schnabel, F., 2012. Breast cancer risk factors in younger and older women. Curr. Aging. Sci. 5(2), 140-147.

Fedorenko, Z.P., Myhaylovich, Y.Y., Gulak, L.O., 2013. Rak v Ukrajini [Cancer in Ukraine] Bulletin of National CancerRegister of Ukraine 2011-2012 (in Ukrainian).

Fung, T.T., Hu, F.B., McCullough, M.L., Newby, P.K., Willett, W.C., Holmes, M.D., 2006. Diet quality is associated with the risk of estrogen receptor-negative breast cancer in postmenopausal women. J. Nutr. 136, 466-472.
Gavrilov, V.B., Gavrilova, A.P., Mazhul', L.M., 1987. Analiz metodov opredeleniya produktov perekisnogo okisleniya lipidov v cyvorotke krovi po testy s tiobarbiturovoy kislotoy [Analysis of methods for determining lipid peroxidation products in the blood serum on test with thiobarbituric acid]. Vopr. Med. Chim. 1, 118-122.

Klebanov, G.I., 1988. Otsenka antiokislitel'noy aktivnosti plazmy krovi s primeneniem geltochnyuch lipoproteidov [Evaluation of antioxidative activity of blood plasma using yolk lipoproteins]. Lab. Delo 5, 59-62 (in Russian).

Larrea, F., Chirinos, M., 2007. Impact on human health of hormonal additives used in animal production. Rev. Invest. Clin. 59(3), 206-211.

Lykholat, T.Y., 2012. Zalezghnist' protsesiv metastazuvannya vid retseptornogo profilyu ta viku chvorych $\mathrm{n}$ arak molotchnoy galozy [The dependence of the process of metastasis from receptor profile and age of patients with breast cancer]. Visn. Lviv. Univ. Biol. 56, 242-247 (in Ukrainian).

Lykholat, T.Y., Antonyuk, S,V., Probatchay, V.I., 2013. Osoblyvosti receptornoi' vidpovidi chynnykiv zrostannja puhlyny u hvoryh na rak molochnoi' zalozy [Features of receptor response of factors of tumor growth in patients with breast cancer]. Vìsn. Dnìpropetr. Unìv. Ser. Bìol. Med. 3(1), 38-43 (in Ukrainian).

Mariani, A., Jeandel, C., Paris, F., Ecochard, R., 2011. Puberty and pubertal growth dynamics in children with idiopathic short stature. J. Pediatr. Endocrinol. Metab. 24(6), 319-325.

Owens, C.W.I., Belcher, R.V., 1965. A colorimetric micromethod for determination of glutathione. Biochem. J. 94(3), 705-711.

Pereslegina, I.A. 1989. Aktivnost' antioxidantnyuch fermentov clunyu zdorovych detey [The activity of antioxidant enzymes saliva of healthy children]. Lab. delo 11, 20-23 (in Russian).

Smolanka, I.I., Sklyar, S.Y., Golovko, T.S., Ganuch, O.V., 2013. Ckryning, profilaktica ta rannya diagnostika raku grudnoy zhelezy [Screening, prevention and early detection of breast cancer]. Clin. Oncol. 8(1), 12-25 (in Ukrainian).

Stephany, R.W., 2001. Hormones in meat: Different approaches in the EU and in the USA. Handb. Exp. Pharmacol. 103, $357-363$.

Stephany, R.W., 2010. Hormonal growth promoting agents in food producing animals. Handb. Exp. Pharmacol. 195, 355367.

Wang, S., Wang, X.H., 2007. Analytical methods for the determination of zeranol residues in animal products: A review. Food Addit. Contam. 24(6), 573-582.

Надійшла до редколегії 08.04.2014 